zemalja I: 195-295. Sarajevo: Centar za Balkanološka Ispitivanja, Akademija Nauka i Umjetnosti Bosne i Hercegovine.

1981. Krško podzemlje Istre kao prostor za naseljavanje fosilnih ljudi, Liburnijske teme 4: 119-35.

MaRKović, C. 1974. The stratigraphy and chronology of the cave Odmut, Archaeologia Iugoslavica 15: $7-11$.

1985. Neolit Crne Gore. Cetinje: Zavod za zaštitu spomenika kulture, SR Crne Gore.

MAROVIĆ, I. 1979. Rezultati arheološkog sondiranja u Gospodskoj pećini kod vrela Cetine, Vjesnik za arheologiju i historiju dalmatinsku 72-3: 13-50.

MÜLLER, J. 1988. Škarin Samograd - eine frühneolitische Station mit monochromer Ware und Impresso Keramik an der Ostadria, Archäologisches Korrespondenzblatt 18/3: 219-35.

In press. Cultural definition and interaction of the eastern Adriatic early neolithic, Berytus 37.

In prep. Das Frühneolithikum der ostlichen Adria.
Ph.D thesis, University of Freiburg.

Riedel, A. 1975. La fauna epipaleolitica della Grotta Benussi (Trieste), in Atti e Memorie Commissione E. Boegan.

SREJOVIĆ, D. 1974. The Odmut cave - a new facies of the Mesolithic culture of the Balcan peninsula, Archaeologia Iugoslavica 15: 3-6.

Tringham, R. 1971. Hunters, fishers and farmers of eastern Europe 6000-3000 BC. London: Hutchinson.

TrumP, D.H. 1980. Prehistory of the Mediterranean. London: Allen Lane.

WhITEHOUSE, R.D. 1968. The early Neolithic of southern Italy, Antiquity 42: 188-93.

Zvelebil, M. (ed.) 1986. Hunters in transition. Cambridge: Cambridge University Press.

ZvelEBil, M. \& P. Rowley-CoNwY. 1984. Transition to farming in northern Europe: a hunter-gatherer perspective, Norwegian Archaeological Review 17/2: 104-28.

\title{
The Latin inscription on the Coppergate helmet
}

\author{
J.W. BINNS, E.C. NORTON \& D.M. PALLISER *
}

The Coppergate helmet, found in central York in 1982 and of Anglo-Saxon date, bears a Latin inscription. A new reading of the inscription is offered, and a different view consequently taken of its significance.

\section{IN NOMINE DNI NOSTRI IHV SCS SPS DI ET OMNIBUS DECEMUS AMEN OSHERE XPI}

The Anglo-Saxon helmet found on the Coppergate site in York in May 1982 bears these words on a single strip of copper alloy which runs from above the nose over the top of the head and down to the top of the neck (Tweddle 1984, resuming and in places correcting Addyman et al. 1982; Pearson et al. 1982; Tweddle 1983). Two other copper alloy bands run up from above the ears to meet the principal inscribed strip at the crown of the helmet, forming a cross over the top of the head (FIGURES 1,2). The band which runs down to the left ear repeats the identical wording IN NOMINE . . SPS, while the opposite piece running down to the right ear contains OMNIBUS ... OSHER. In both cases the inscription reads from the top of the helmet downwards, but it is evident that the left hand piece was inadvertently reversed during the construction of the helmet, and that the inscription was intended to be read from behind and from left to right, starting IN NOMINE ... over the left ear, and ending ... OSHER over the right. Apart from this reversal of the first part of the inscription, some of the letters of the text are missing on the right hand side. Since the helmet is oval shaped, the inscribed band running from front to back is longer than the transverse pieces running from ear to ear, and the craftsman apparently failed to accommodate the full text

* J.W. Binns \& E.C. Norton, Centre for Medieval Studies, University of York, King's Manor, York Yo1 2kr. D.M. Palliser, Department of History, University of Hull, Hull HU6 7RX.

ANTIQUTY 64 (1990): 134-9 


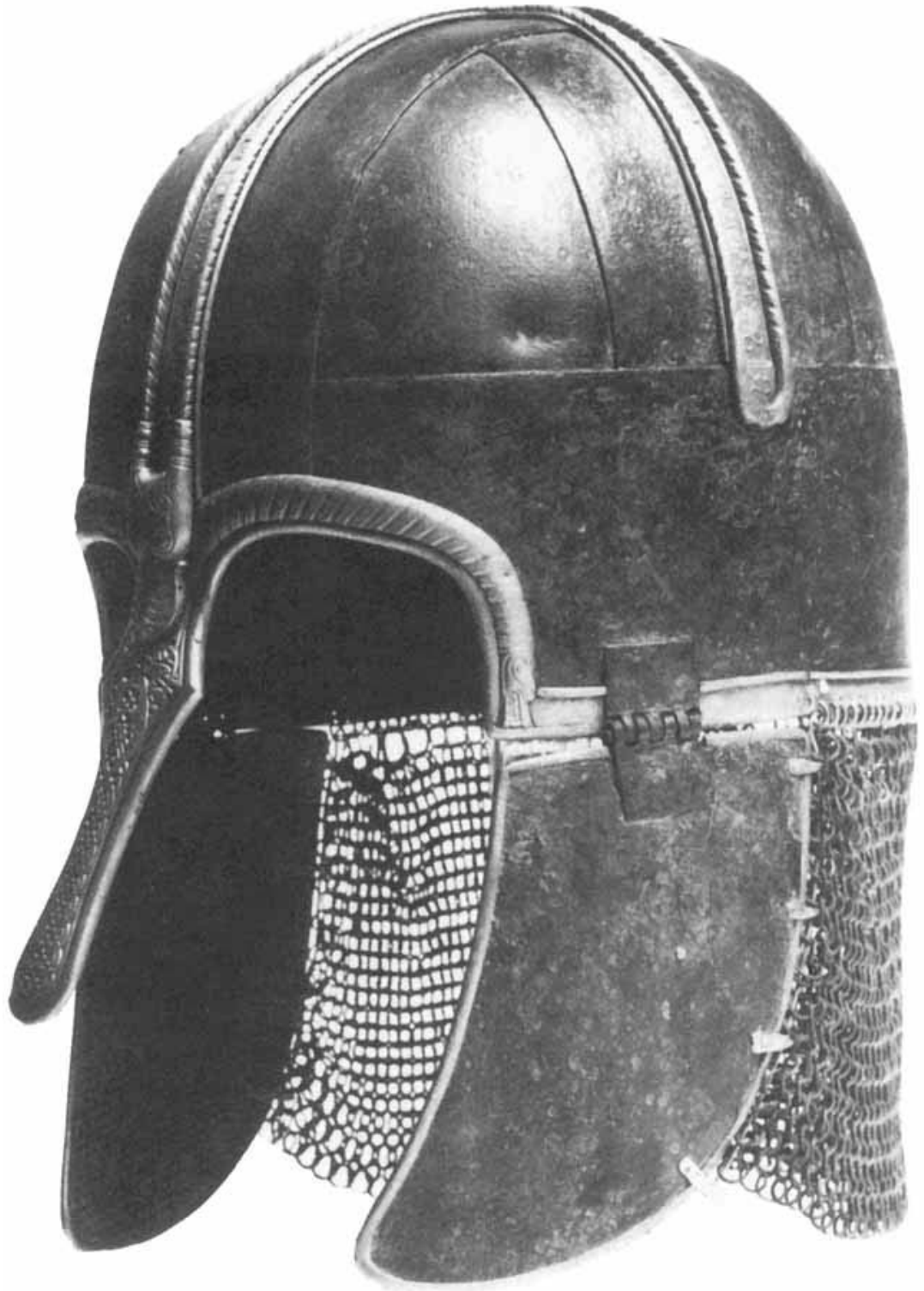

FIGURE 1. The Coppergate helmet, after restoration. (Photo courtesy of York Castle Museum.) within the reduced space available. The whole sentence may have actually been written out on the transverse bands, and part probably had to be cut off when they were fastened in position. The craftsman also had problems with the individual letters on both inscriptions: many are upside down, and back to front. However, the word order is correct throughout, and it is clear that the design envisaged the same sentence repeated from front to back and from side to side across the top of the helmet.

\section{Translation}

The letters were made by the repoussé technique and must therefore belong to the original construction of the helmet, which has been dated on stylistic grounds to the third quarter of the 8th century. What does this text mean, and what is its significance? Tweddle (1984: 17) comments:

The main part of this can be freely translated 'In the name of our Lord Jesus the Holy Spirit God the Father 


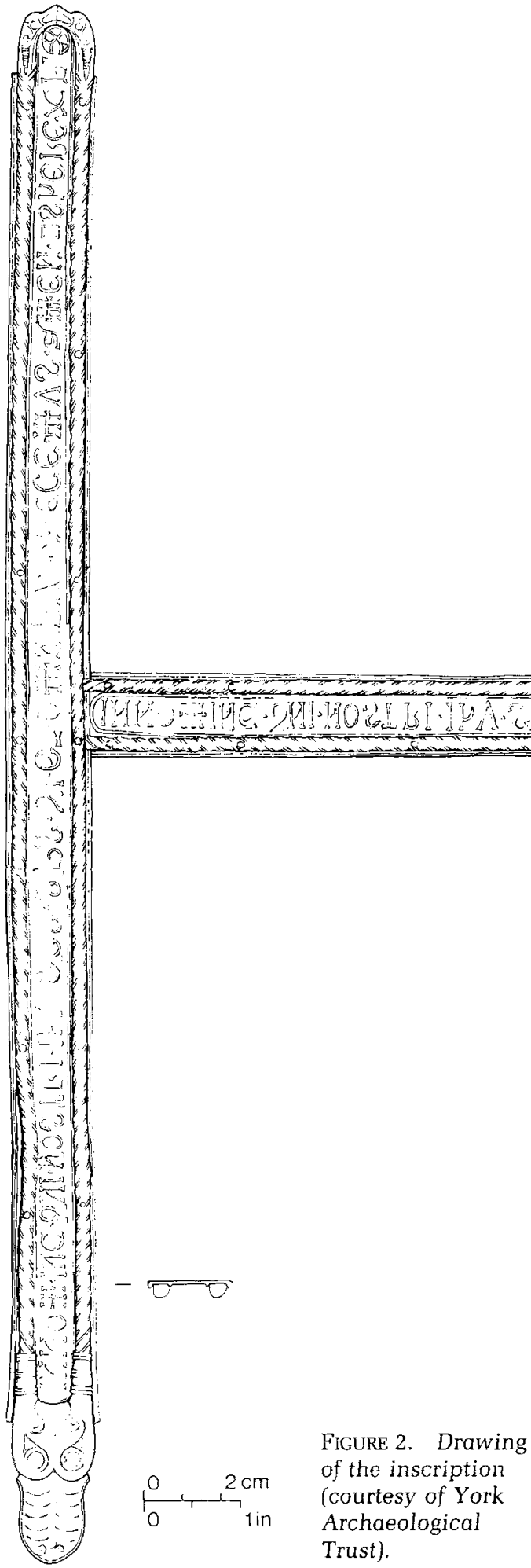

and with all we pray. Amen'. OSHERE is an AngloSaxon personal name, and the letters XPI are the first three letters of the word Christ in Greek.

There are various difficulties with this rendering. In the first place, 'we pray' does not appear in the Latin at all. Tweddle has apparently taken DECEMUS as DICIMUS (we say or speak), and thus, in this context, we pray. SCS SPS, as an abbreviation for Sanctus Spiritus, is grammatically wrong; it should be in the genitive. This translation would therefore postulate a basic grammatical error on an object on which a great deal of care and attention had clearly been lavished. The word ET is redundant, and 'with all we pray' is awkward. If OMNIBUS were to mean 'with all', one would expect it to be preceded by CUM. By itself, it would more naturally mean 'to or for all'. But, even granting that it meant 'with all', 'with all' whom? Why not just 'we all pray'? The name OSHERE stands

isolated from the meaning of the rest of the text. Finally, it should be noted that XPI is the standard abbreviation for the Latin CHRISTI (using the normal Greek letter forms X and P), not the first three letters of Christos in Greek just as the Greek letter form $\mathrm{H}$ is used for the Latin $\mathrm{E}$ in abbreviating the name of Jesus.

The published translation of the inscription given by Tweddle (and also displayed to the public in the Castle Museum at York) therefore needs revision. We should like to propose an alternative rendering which we believe makes better sense, and may throw light on the helmet's significance. We start by assuming that, where sense can be made from the Latin as it stands, it is unnecessary to postulate grammatical error. Accordingly, we believe that SCS is not an incorrectly abbreviated genitive of SANCTUS, but a correctly abbreviated dative or ablative plural SANCTIS. It then clearly goes with OMNIBUS, and in context would mean 'to all [the] Saints'. The other abbreviations are not problematic: DI for DEI appears, for instance, twice in Anglo-Saxon inscriptions in the form AGNUS DI (Okasha 1971: nos 17, 33).

The key to the undoubted difficulty of this text lies in the word DECEMUS, which does not 
exist in Latin and must perforce be emended in some way. Rather than altering both vowels to DICIMUS, which gives no very clear sense, the emendation of a single letter would give us DICEMUS, from DICARE, to dedicate or offer. DICARE appears four times, as opposed to DEDICARE once, in the famous poem on York by Alcuin, who was of course at the school there at the very period when the helmet is believed to have been made (Godman 1982: vv. 504, 1138, 1155,1493 ). In this case the only possible object for the verb is Oshere himself, the name being left in the Anglo-Saxon. Finally, the ET can only be a copula between IHV XPI and SPS DI. Recasting the text in its sense order, we get:

\section{IN NOMINE DNI NOSTRI IHV XPI ET SPS DI OMNIBUS SCS DECEMUS OSHERE AMEN.}

In the name of our Lord Jesus Christ and of the Spirit of God, let us offer up Oshere to All Saints. Amen.

\section{Discussion}

This accounts for every word without forcing the grammar. It makes excellent sense as an invocation of divine protection for the owner, Oshere, through the intercession of All Saints. As Tweddle rightly comments (1984: 18), the inscriptions 'were evidently intended to give a spiritual dimension to the protection afforded by the helmet. . . . It may also be deliberate that when viewed from the top the two strips form a cross.' Its significance is not merely the use of the Christian symbol par excellence; it is also strongly reminiscent of the late antique and Carolingian custom, practised by, for example, Optatianus Porfyrius, Venantius Fortunatus, and Rhabanus Maurus, of writing poetry - and particularly Christian poetry - in the shape of a cross. Alcuin himself wrote a poem of this type (Duemmler 1881:225). The genre was doubtless familiar to the educated circles associated with the York school and may explain the rather convoluted word-order of the Coppergate helmet inscriptions, even though the sentence itself can be construed as actual verse only by wilfully disregarding many of the formal quantities of the syllables.

Nevertheless, poems of this kind were highly artificial. The displacement of XPI to the end of the sentence not only enables the text to begin and end with Christ ('I am the Alpha and the Omega, the beginning and the end'), but also allows the final I of XPI to mirror the initial I of $\mathrm{N}$
NOMINE. Intentional mirroring of initial and final letters is found in the cross poetry of Optatianus Porfyrius (Polara 1973: I, 8 and $69-$ mirroring of $\mathrm{S}$ and A) Venantius Fortunatus (Leo 1881: 30 - mirroring of I) and Rhabanus Maurus (Migne 1864: cols 155-6, 202, 257-8mirroring of $\mathrm{O}, \mathrm{I}$ and $\mathrm{S}$ ). Moreover, Rhabanus Maurus points out that the letter I has a numerical value of one in the Latin alphabet and identifies this number with Christ (Migne 1864: cols 210,238 ). The complicated word order in the middle of the sentence may also be explicable in these terms. In its actual abbreviated form the text contains 57 letters, making the middle letter the E of ET, immediately adjacent to DI, God, while when written out in full without contractions the text contains 75 letters, the middle letter then being the $U$ of SPIRITUS DI. The symbolism seems clear: in the centre of all things (and physically speaking at the top of the helmet) is the Spirit of God, flanked by all the Saints, with whom Oshere associates himself within the limits of this earthly existence whose boundaries are set by Christ, the beginning and the end. This structure, although desperately artificial to the modern mind, is entirely characteristic of the highly formalized literary conventions of the time.

Furthermore, a votive invocation of All Saints is reinforced by a consideration of the find spot. The archaeological evidence is ambiguous as to whether or not the helmet was accidentally deposited (Tweddle 1984: 22), but the find is close to All Saints' Church, and the inscription is consistent with the dedicatees of that church being invoked as a protection to Oshere.

The difficulty with such an explanation is one of dating. If the helmet is indeed of c. 750-75, then it is three centuries earlier than the first documentary record of the church in 1086, when it was held by the bishop of Durham 'of the king's gift', de dono regis (Domesday Book, I, fo. $288 \mathrm{r}$.). The RCHM suggest that its position 'would be consistent with it[s] being a Danish foundation of the 10th century' and they record a grave-cover of the 10th or early 11 th century (RCHM 1981: 1-2). Another significant find from All Saints is a set of polychrome relief tiles, discovered in the remains of the 12 thcentury south transept in 1963. They would appear however to have been re-used, as they belong to a small series of late Saxon tiles dated 
to the century or so before the Norman conquest (Gem \& Keen 1981: 20-26). Elsewhere in England, tiles of this type have been found only at major ecclesiastical sites - St Alban's Abbey, Coventry (Stokes \& Tweddle 1986), Peterborough Abbey, the Old Minster at Winchester and perhaps Westminster Abbey. All Saints Pavement stands out strangely amongst such illustrious companions: the presence of the tiles strongly suggests that it was in the late Saxon period no ordinary local church, but a much more important establishment.

Although there has been little archaeological exploration beneath the church, negative evidence need not mean that the church cannot have originated before the 10th century. One pointer to an early origin may be a grant of $c$. $1170 \times 1185$ of a messuage in Coppergate ante monasterium Omnium Sanctorum (Farrer 1914: I, no. 229). The implication is not that All Saints was a 'monastery', as Farrer translated the term, but a minster, that is, a mother church which had at some time housed a community of priests, whether or not it had ever been monastic in the strict sense. The tiles would make better sense in a minster church. Minsters generally originated in the 7 th and 8 th centuries, with wide territories (parochiae) dependent on them; they lost ground between the 10th and 12 th centuries as local and private churches with resident priests replaced them, but they often preserve the name of minster (Blair 1988a). Frequently they were founded near royal vills, and were important elements in the growth of towns (Blair 1988b). Admittedly the monasterium reference is late, from a period when mynster was sometimes used simply as a synonym for 'church' (Morris 1989: 158) but that need not mean that All Saints was not called a mynster before the conquest, only that virtually no pre-conquest documents survive for the city of York. A dedication stone found in
St Mary's, Castlegate, the next parish church to the south, refers to a minster, whose dedication includes St Mary, St Martin, St Cuthbert and All Saints. The inscription is datable to the 10 th or 11th century (Okasha 1971: 131; RCHM 1981: 33 ), and this provides an unambiguously preconquest reference. In addition to All Saints and St Mary's, two other nearby post-conquest churches are individually dedicated to St Martin and St Cuthbert, though the precise relationship of the four parish churches to the Saxon Minster remains a matter of conjecture. An early dedication to All Saints would fit well with the developing liturgical practice of 8thcentury Northumbria. Although Levison's list of English church dedications of the 7 th and 8 th centuries does not include any to All Saints (Levison 1946: 259-65), both Levison and before him Wilmart demonstrated that the festival of All Saints was adopted in Northumbria in the 8th century, and that it was probably Alcuin who subsequently transmitted it to the Frankish dominions (Levison 1946: 160; Wilmart 1934: $51,55,64)$.

It is therefore a strong possibility that All Saints in Ousegate (as it was usually called) was descended from a minster church which was not an Anglo-Scandinavian foundation but an early royal minster of the 7 th or 8 th century, established outside the Roman fortress as a mother-church of the growing town to the south. Such an origin would fit well with the monasterium reference and with the royal ownership before the conquest, and it would allow the Coppergate helmet to be seen as invoking the protection of his local minster on Oshere.

Acknowledgements. We would like to thank Dr J. Blair and $\mathrm{Mr}$. Campbell for making various helpful suggestions in the light of their specialist knowledge.

\section{References}

Addyman. P.V., N. Pearson \& D. Tweddle. 1982. The Coppergate helmet, Antiquity 56: 189-94.

BLAIR, J. 1988a. Introduction: from minster to parish church, in J. Blair (ed.), Minsters and parish churches: the local church in transition 950 1200: 1-19. Oxford: Oxford University Committee for Archaeology. Monograph 17.

1988b. Minster churches in the landscape, in D.
Hooke (ed.), Anglo-Saxon settlements: 35-58. Oxford: Basil Blackwell.

Duemmler, E. (ed.). 1881. Poetae Latini Aevi Carolini 1: Monumenta Germaniae Historica. Berlin: Weidmann.

FARRER, W. 1914. (ed.), Early Yorkshire charters. Edinburgh: privately printed by Ballantine, Hanson \& Co.

GEM, E. \& L. KEEN. 1981. Late Anglo-Saxon finds from 
the site of St Edmund's Abbey, Proceedings of the Suffolk Institute of Archaeology 35(1): 1-30.

Godman, P. (ed.). 1982. Alcuin, The Bishops, Kings, and Saints of York. Oxford: Clarendon Press. Oxford Medieval Texts.

LEO, F. (ed.). 1881. Venantius Fortunatus, Opera poetica. Monumenta Germaniae Historica, Auctores Antiquissimi 4(1). Berlin: Weidmann.

LEvison, W. 1946. England and the continent in the eighth century. Oxford: Clarendon Press.

Migne, J.P. (ed.). 1864. Rhabanus Maurus, Opera omnia, vol. 1, Patrologia latina, vol. 107. Paris: Migne.

MORRIS, R. 1989. Churches in the landscape. London: Dent.

OKASHA, E. 1971. Hand list of Anglo-Saxon nonRunic inscriptions. Cambridge: Cambridge University Press.

Pearson, N., D. Tweddle, R. Hall \& J. Spriggs. 1982. A close shave: the Coppergate helmet, Interim;
Bulletin of the York Archaeological Trust 8(4): 8-36.

POLARA, J. 1973 (ed.), Publilius Optatianus Porfyrius, Carmina, Corpus Scriptorum Latinorum Paravianum. Turin: Paravia.

RCHM. 1981. An inventory of the historical monuments in the city of York 5: The central area. London: Royal Commission on Historical Monuments.

STOKES, M.A. \& D. TwEDdLE. 1986. Late Saxon tiles from Coventry, Medieval Ceramics 10: 29-36.

TwEDDLE, D. 1983. Coppergate helmet: update, Interim: Bulletin of the York Archaeological Trust 9(2): $2-4$.

1984. The Coppergate helmet. York: York Archaeological Trust.

WILMART, A. 1934. Un témoin Anglo-Saxon du calendrier métrique d'York, Revue Bénédictine 46: $41-69$.

\section{On concepts expressed in southern African rock art}

\section{J.F. THACKERAY*}

Prehistoric rock art in southern Africa has been studied - with remarkable success - in the light of ethnographic data obtained from modern 'San' or 'Bushmen'. Yet examples of rock paintings reflect conceptual associations similar if not identical to those identified among Bantu-speakers. It is recommended that the art be studied in the light of linguistic as well as ethnographic data without adopting a 'San-centric' stance.

\section{Introduction}

An understanding of rock art in southern Africa has been greatly advanced by the recognition that paintings and engravings reflect concepts associated with trance (Lewis-Williams 1981). Thus paintings of therianthropic figures, including so-called 'trance-buck' such as the one reproduced in FigURE 1, can be recognized as imagery associated with the hallucinations of shamans or 'medicine-men'. This recognition has stemmed from analysis of ethnographic records of 'San' or 'Bushmen', under an assumption that concepts held by prehistoric artists were those held by modern 'San' huntergatherers. The art has been referred to as 'The
San artistic achievement' (Lewis-Williams 1985); but, since rock paintings and engravings have considerable antiquity ('Thackeray 1983) and since interaction between 'San'/"Bushmen' and other population groups in southern Africa is known to have occurred, is it correct that concepts expressed in the art were held by people who can be grouped into a single category labelled 'San'? And should the study of rock art in southern Africa become rigorously 'San-centric', concentrating on concepts, beliefs, customs and languages of modern hunter-gatherers that are assumed to have been direct descendants of the prehistoric artists?

At least some of the concepts, customs and

* I.F. Thackeray, Department of Archaeology, University of Cape Town, 7700 Rondebosch, South Africa 